\title{
FAKTOR-FAKTOR YANG BERPENGARUH TERHADAP PRODUKSI KAKAO DI KECAMATAN BUA KABUPATEN LUWU
}

\author{
Sapar $^{1}$, Rismawati $^{2}$, Adrian $^{3}$ \\ 1) Dosen Sekolah Tinggi Ilmu Ekonomi Muhammadiyah Palopo \\ ${ }^{2,3)}$ Dosen Sekolah Tinggi Ilmu Ekonomi Muhammadiyah Palopo
}

\begin{abstract}
Abstrak: Penelitian ini berjudul "Faktor-Faktor Yang Berpengaruh Terhadap Produksi Kakao Di Kecamatan Bua Kabupaten Luwu". Tujuan penelitian ini adalah untuk mengetahui besar pengaruh modal,luas lahan,teknologi,dan pupuk ketingkat produksi petani kakao dikecamatan bua kabupaten luwu.

Dalam Penulisan Skripsi ini metode yang dipergunakan adalah Waktu dan tempat penelitian adapun waktu penelitian dilakukan pada bulan Maret 2015 sampai pada bulan Mei 2015 dan tempat peneliatian dilakukan di Kecamatan Bua Kabupaten Luwu.

Jenis dan sumber data yang digunakan adalah data primer yaitu data yang diperoleh langsung melalui penelitian lapangan atau pengamatan lapangan,wawancara langsung terhadap para petani kakao ditempat dan data sekunder yaitu data yang diperoleh melalui buku literatur atau buku bacaan lainnya seperti tulisan-tulisan ilmia,teori-teori,diktat dan pendapatan-pendapatan yang digunakan dalam penelitian. Populasi dan sampel pengertian populasi yaitu keseluruhan objek yang mempunyai kualitas dan karakteristik tertentu yang ditetapkan oleh peneliti untuk dipelajari dan kemudian ditarik kesimpulannya sedangkan sampel yaitu sejumlah anggota yang dipilih/diambil dari suatu populasi. Metode pengumpulan data untuk menganalisa data yang digunakan dalam penelitian digunakan analisis regresi berganda.
\end{abstract}

Kata Kunci: Produksi Kakao

\section{PENDAHULUAN}

Kakao merupakan salah satu hasil pertanian Indonesia cukup potensial untuk meningkatkan devisa Negara di tingkat dunia. Kakao Indonesia menempati posisi ketiga setelah Pantai Gading dan Ghana. Hal ini didukung dengan areal tanaman di Indonesia yang masih banyak tersedia, tenaga kerja dan tenaga ahli kakao. Kakao juga merupakan salah satu komoditas unggulan di dari sub sektor yang berkembang di Sulawesi Selatan, sebagian besar diusahakan petani dalam bentuk perkebunan rakyat.

Besarnya kontribusi perkebunan kakao terhadap pendapatan petani merupakan masalah penting bagi pengembangan skala usaha tani. Pendapatan yang diperoleh dari suatu usaha tani berkaitan erat dengan produksi. Jika dibandingkan dengan produksi kakao ditingkat hasil penelitian yang mencapai 2-3 ton/ha, maka produksi kakao di
Sulawesi Selatan tergolong masih rendah. Rendahnya produksi ini dapat disebabkan oleh belum optimalnya teknologi budidaya.

Sebagian besar lahan pertanaman kakao di Sulawesi Selatan memiliki tingkat kesuburan tanah yang sangat beragam dari sangat rendah sampai tinggi. selain itu penanaman tanaman kakao yang dilakukan oleh masyarakat sering kali mengabaikan pertimbangan konservasi lahan, akibatnya proses kehilangan kesuburan tanah semakin meningkat setiap tahunnya.

Melihat permasalahan dan kendala tersebut maka produksi yang diperoleh belum optimal. Peningkatan produksi dapat diperoleh dengan mengalokasikan input produksi secara tepat dan berimbang. Hal ini berarti petani secara rasional melakukan usaha tani dengan tujuan meningkatkan produksi untuk memaksimumkan keuntungan. 
Oleh karena itu diperlukan analisis faktor-faktor yang mempengaruhi perkembangan usaha tani kakao khususnya terhadap pendapatan petani.

Pengembangan kakao di Indonesia tersebar di beberapa wilayah dan termasuk propinsi sentra produksi kakao adalah propinsi Sulawesi Selatan, Sulawesi Tenggara, Sulawesi Tengan, Lampung dan Propinsi Bali. Dalam agribisnis kakao ada beberapa kendala yang dihadapi, khususnya dalam peningkatan produktivitas dan kualitas yang dihasilkan antara lain adalah masih mempergunakan teknologi tradisonal dengan bahan tanaman yang tidak berasal dari klon atau biji yang terpilih dan dengan budidaya yang kurang memadai, serta serangan organism pengganggu tanaman (OPT) berupa hama dan penyakit.

Selain permasalahan tersebut, dalam era globalisasi dewasa ini terdapat tuntutan terhadap produk yang dihasilkan harus memenuhi kualitas yang tinggi dan proses produksi akrab lingkungan. Fakta dilapangan menunjukkan bahwa pengendalian hama di tingkat produsen saat ini masih terbatas pada penggunaan pestisida saja, sementara tuntutan konsumen mengarah kepada persyaratan lingkungan yang diakui oleh WTO (ISO 14000) dan Codex Alimentarius (adanya ambang batas maksimum kandungan zat tambahan, logam berat, residu pestisida dan bahan pencemar lainnya). Artinya, apabila kakao Indonesia ingin bersaing di pasar Global maka mau tak mau persyaratan tersebut harus dipenuhi.

Kecamatan Bua merupakan salah satu Kecamatan yang mempunyai potensi untuk mengembangkan tanaman kakao dimana luas wilayah perkebunan Kecamatan Bua adalah 3.857 Ha.

\section{BAHAN DAN METODE}

Jenis dan sumber data yang digunakan dalam penelitian ini yaitu data primer dan sekunder. Populasi dalam penelitian ini adalah seluruh petani kakao di Kecamatan Bua Kabupaten Luwu yang berjumlah 2.640 orang. Dengan menggunakan rumus Slovin dengan tingkat kepercayaan 90\% maka jumlah sampel adalah 81 orang.

Untuk menganalisa data yang digunakan dalam penelitian ini digunakan analisis regresi berganda (Hardiana, 2013: 35) dengan rumus sebagai berikut:

$\mathrm{Y}=\mathrm{a}+\mathrm{b}_{1} \mathrm{x}_{1}+\mathrm{b}_{2} \mathrm{x}_{2}+\mathrm{b}_{3} \mathrm{x}_{3}+\mathrm{b}_{4} \mathrm{x}_{4}$

Dimana:

$$
\begin{array}{ll}
\mathrm{Y} & =\text { Tingkat produksi petani kakao } \\
\mathrm{X}_{1} & =\text { Modal }(\mathrm{Rp}) \\
\mathrm{X}_{2} & =\text { Luas Lahan }(\mathrm{Ha}) \\
\mathrm{X}_{3} & =\text { Teknologi } \\
\mathrm{X}_{4} & =\text { Pupuk } \\
\mathrm{a} & =\text { Konstanta } \\
\mathrm{b} 1, \mathrm{~b}_{2}, \mathrm{~b}_{3} & =\text { Angka parameter yang dicari }
\end{array}
$$

\section{HASIL DAN PEMBAHASAN}

\section{Analisis Regresi Berganda}

Berikut ini adalah uraian hasil pengujian regresi berganda antara kinerja penyuluh pertanian dengan kompetensi petani kakao dan output tabel pengujian dengan menggunakan bantuan program SPSS versi 20 
Tabel Koefisien antara Modal,Luas

Lahan,Teknologi, Pupuk

Correlation

\begin{tabular}{|c|c|c|c|c|c|c|c|c|}
\hline \multirow{2}{*}{\multicolumn{2}{|c|}{ Model }} & \multicolumn{2}{|c|}{ Untandardized Coefficients } & Standardized & \multirow{2}{*}{$\mathrm{T}$} & \multirow{2}{*}{ Sig } & \multicolumn{2}{|c|}{ Correlations } \\
\hline & & & Std.Error & Beta & & & Zero-Order & Partai \\
\hline \multirow[t]{5}{*}{1} & (Contanst) & 3858.250 & 1961.480 & & 1.967 & .053 & & \\
\hline & Modal & -461.833 & 448.631 & -.131 & -1.029 & .307 & -.130 & -.117 \\
\hline & Luas- Lahan & .058 & .080 & .088 & .721 & .437 & .119 & .082 \\
\hline & Teknologi & 648.216 & 648.216 & .029 & .218 & .828 & -.005 & .025 \\
\hline & Pupuk & 778.714 & 778.714 & .096 & .844 & .401 & .101 & .096 \\
\hline
\end{tabular}

Berdasarkan Pada Tabel di atas dapat dijelaskan bahwa Korelasi antara Modal,Luas Lahan,Teknologi,Pupuk terdapat perbedaan yang sangat tinggi.

Tabel Anova antara kinerja perbaikan pertanian dengan

kompetensi petani kakao

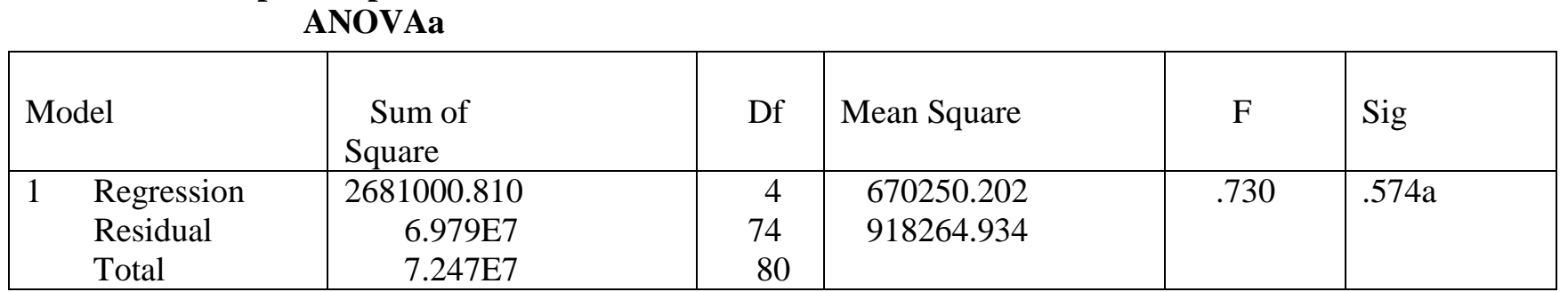

Tabel koefisien determinasi antara kinerja perbaikan pertanian dengan kompetensi petani kakao Model Summaryb

\begin{tabular}{|c|c|c|c|c|c|c|c|c|}
\hline \multirow[b]{2}{*}{ ModeI } & \multirow[b]{2}{*}{$\mathrm{R}$} & \multirow[b]{2}{*}{ R Square } & \multirow[b]{2}{*}{$\begin{array}{l}\text { Adjusted R } \\
\text { Square }\end{array}$} & \multirow[b]{2}{*}{$\begin{array}{l}\text { Std.Error of } \\
\text { The Estimate }\end{array}$} & \multicolumn{4}{|c|}{ Change Statistics } \\
\hline & & & & & R Squre & F Change & Df1 & Df2 \\
\hline 1 & $.192 \mathrm{a}$ & .037 & -.014 & 958.26141 & .037 & .730 & 4 & 76 \\
\hline
\end{tabular}


Berdasarkan pada tabel di atas dapat kita ketahui nilai koefisien regresi, keofisien determinasi, nilai f hitung, t hitung, signifikasi dan sebagainya antara modal, Luas lahan, Teknologi, dan Pupuk terhadap produksi kakao. Penjelasan hasil analisi regresi dan pengujian $t$ dan $\mathrm{f}$ sebagai berikut:

Analisis Regresi Linier Berganda

Persamaan Regresi Berganda adalah

$\mathrm{Y}=\mathrm{a}+\mathrm{b} 1 \mathrm{x} 1+\mathrm{b} 2 \mathrm{x} 2+\mathrm{b} 3 \mathrm{x} 3+\mathrm{b} 4 \mathrm{x} 4$

$\mathrm{Y}=3858,250-0,131 \mathrm{X} 1+0,88 \mathrm{X} 2+0,029 \mathrm{X} 3+$ $0,096 \times 4$

Keterangan :

$\mathrm{Y}=$ Produksi

$\mathrm{X} 1=$ Modal

$\mathrm{X} 2=$ Luas Lahan

X3= Teknologi

X4= Pupuk

$\mathrm{a}=$ nilai konstanta

$\mathrm{b}=$ koefien regresi

Penjelasan persamaan tersebut sebagai berikut:

a. Konstanta sebesar 3858,250. Artinya jika modal, luas lahan, teknologi dan pupuk nilainya 0 , maka produksi kakao nilainya 3858,250 .

b. Koefisien regresi modal sebesar $-0,13$, luas lahan sebesar 0,88, satuan. Koefisien bernilai positif artinya hubungan antara luas lahan, teknologi dan pupuk dengan produksi kakao. Adalah positif yang artinya semakin tinggi luas lahan, teknologi dan pupuk maka semakin meningkat produksi kakao.

\section{Pengujian Hipotesis}

a. Pengaruh antara modal terhadap produksi.
Uji t (uji koefisien regresi berganda) digunakan untuk mengetahui pengaruh secara signifikan antara modal terhadap produksi kakao.

Langkah-langkah dalam pengujian hipotesis sebagai berikut :

1. Menentukan hipotesis

Ho = Modal tidak berpengaruh terhadap produksi kakao.

$\mathrm{Ha}=$ Modal berpengaruh terhadap produksi kakao.

2. Menentukan tingkat signifikan : Tingkat signifikan menggunakan 0,05.

3. Menentukan thitung berdasarkan tabel di atas di peroleh t hitung sebesar -1029 .

b. Pengaruh antara luas lahan terhadap produksi. Uji t (uji koefisien regresi berganda) digunakan untuk mengetahui pengaruh secara signifikan antara luas lahan terhadap produksi kakao.

Langkah-langkah dalam pengujian hipotesis sebagai berikut :

1. Menentukan hipotesis

Ho = Modal tidak berpengaruh terhadap produksi kakao.

$\mathrm{Ha}=$ Modal berpengaruh terhadap produksi kakao.

2. Menentukan tingkat signifikan : Tingkat signifikan menggunakan, 437

3. Menentukan t hitung berdasarkan tabel di atas di peroleh t hitung sebesar, 721

c. Pengaruh antara teknologi terhadap produksi Uji t (uji koefisien regresi berganda) digunakan untuk mengetahui pengaruh secara signifikan antara pupuk terhadap produksi kakao. 
Langkah-langkah dalam pengujian hipotesis sebagai berikut :

1. Menentukan hipotesis

Ho = Modal tidak berpengaruh terhadap produksi kakao.

$\mathrm{Ha}=$ Modal berpengaruh terhadap produksi kakao.

2. Menentukan tingkat signifikan : Tingkat signifikan menggunakan, 828

3. Menentukan t hitung berdasarkan tabel di atas di peroleh $t$ hitung sebesar, 218

d. Pengaruh antara pupuk terhadap produksi

Uji t (uji koefisien regresi berganda) digunakan untuk mengetahui pengaruh secara signifikan antara modal terhadap produksi kakao.

Langkah-langkah dalam pengujian hipotesis sebagai berikut :

1. Menentukan hipotesis

Ho = Modal tidak berpengaruh terhadap produksi kakao.

$\mathrm{Ha}=$ Modal berpengaruh terhadap produksi kakao.

2. Menentukan tingkat signifikan : Tingkat signifikan menggunakan, 401

3. Menentukan t hitung berdasarkan tabel di atas di peroleh t hitung sebesar, 844

Membandingkan $t$ hitung dengan $t$ tabel : nilai $\mathbf{t}$ hitung $>\mathrm{t}$ tabel $\quad(-1,029,721$, $218,844>307,437,828,401$ )

\section{Pembahasan}

Pengaruh kinerja modal, luas lahan, teknologi dan pupuk terhadap kompetensi petani kakao
Hasil penelitian menunjang bahwa perubahan kinerja modal, luas lahan, teknologi dan pupuk berpengaruh nyata terhadap kompetensi petani kakao. Kinerja modal, luas lahan, teknologi dan pupuk ikut menentukan baik buruknya kompetensi petani kakao dengan koefisien pengaruh sebesar 3858,250 satuan pada a 0,05.

Pengaruh kinerja modal, luas lahan, teknologi dan pupuk pada kompetensi petani kakao tampak pada baik buruknya perencanaan model untuk melaksanakan model pertanian, evaluasi dan pelaporan model, pengembangan model, mengembangkan propesi model, kinerja kepemimpinan modal, luas lahan, teknologi dan pupuk diseminasi teknologi dan komunikasi pertanian, kinerja kemitraan usaha dan mengembangkan teknis budidaya kakao. Jika terjadi peningkatan satu- satuan kinerja modal, luas lahan, teknologi dan pupuk akan meningkatkan kemampuan petani kakao sebesar 3858,250 satuan pada a 0,05 .

Kemampuan merencanakan modal, luas lahan, teknologi dan pupuk meliputi kemampuan membuat rencana pembelajaran usaha tani kakao. Kemampuan menyusun rumusan hasil pengumpulan data potensi wilayah dan agroekosistem, kemampuan merumuskan hasil kebutuhan spesifik lokasi yang sesuai dengan kebutuhan petani, kemampuan menyusun program model yang mengakomodir kebutuhan petani, kemampuan menyusun rencana kerja yang jelas, terukur dan terealisasi, dan kemampuan menyusun metode model yang sesuai dengan materi perbaikan dan karakteristik petani.

Kemampuan melaksanakan modal, luas lahan, teknologi dan pupuk meliputi adanya 
kemampuan melaksanakan pembelajaran usaha tani kakao, kemampuan perbaikan materi dengan model yang sesuai dengan kebutuhan karakteristik petani, kemampuan menerapkan metode perbaikan yang berpariasi dan sesuai dengan materi perbaikan dan karakterristik petani dan kemampuan mengembangkan kelompok tani menjadi kelompok yang lebih besar terkait dengan pengembangan usaha taninya.

Kemampuan mengevaluasi dan melaporkan modal, luas lahan, teknologi dan pupuk meliputi kemampuan mengevaluasi efektivitas program, kemampuan mengumpulkan data tentang input, aktifitas, kehadiran peserta dan reaksi terhadap program, kemampuan membuat laporan dan rencana tindak lanjut, kemampuan mengevaluasi dampak perbaikan serta mengkomunikasikan hasil evaluasi kepada pihak-pihak yang bersangkutan.

Kemampuan mengembangkan modal, luas lahan, teknologi dan pupuk meliputi kemampuan menyusun pedoman teknis dan pelaksanaan model untuk acuan perbaikan dalam melaksanakan tugasnya, kemampuan merumuskan hasil kajian arah kebijakan perbaikan, kemampuan merumuskan hasil konsep baru metode perbaikan.

Kemampuan mengembangkan propesi modal, luas lahan, teknologi dan pupuk meliputi kemampuan dalam keikutsertaan atau keaktifan dalam perkumpulan propesi tingkat kabupaten, provinsi dan nasional, kemampuan mengunjungi sumbersumber informasi teknologi pertanian, kemampuan mengakses informasi menggunakan internet, kemampuan mengikuti kegiatan magang atau studi banding dan kemampuan membuat tulisan ilmiah atau populer dan diterbitkan dalam majalah atau surat kabar.
Kemampuan Kepemimpinan modal, luas lahan, teknologi dan pupuk meliputi kemampuan menerapkan gaya kepemimpinan, kemampuan menerapkan keterampilan memimpin, kemampuan menunggu kembangkan kelompok tani dan kemampuan mengembangkan kepemimpinan kelompok tani dengan cara melatih ketua kelompok tani untuk mengembangkan perencanaan, berkomunikasi dengan anggota, berkoordinasi, supervisi, membangkitkan semangat dan memonitor.

Kemampuan diseminasi teknologi meliputi kemampuan menggunakan media cetak dan audio visual, kemampuan melakukan pameran teknologi pertanian, kemampuan menggunakan komunikasi tatap muka, dan kemampuan melakukan studi banding serta menggunakan petak percontohan.

Kemampuan komunikasi modal, luas lahan, teknologi,dan pupuk meliputi kemampuan membuat media perbaikan, kemampuan memahami dan mendengarkan petani, kemampuan menjelaskan, memberi inspirasi, berterimah kasih dan toleran terhadap petani, kemampuan mendorong dan membantu petani untuk dan mencapai tujuan dan kemampuan mendisiplikan diri serta memotivasi petani.

Kemampuan kemitraan usaha meliputi kemampuan mencari mitra usaha, kemampuan mengidentifikasi dan menginventarisasi sumbersumber permodalan lokal, kemampuan untuk membimbing penyedian agro input, penyimpanan dan pemasaran hasil.

Kemampuan teknis budidaya kakao meliputi kemampuan mempersiapkan lahan kakao, kemampuan dalam pembibitan kakao,kemampuan melakukan penanaman kakao, kemampuan 
melakukan konservasi dan persiapan lahan,kemampuan melakukan pemangkasan,pemupukan, kemampuan melakukan pengendalian hama, gulma dan penyakit, kemampuan melakukan panendan pasca panen seperti pemetikan dan sortasi buah kakao. Pemeraman atau penyimpanan buah kakao, pemecahan buah kakao, fermentasi buah kakao, perendaman, pengeringan, tempeng dan sortasi buah kakao.

Dimensi pengubah kinerja modal, luas lahan,teknologi dan pupuk yang berpengaruh pada proses dan hasil dan pelaksanaan perbaikan prtanian, terdiri dari :

Persiapan modal, luas lahan, teknologi dan pupuk yang meliputi rencana pembelajaran usaha tani kakao, tersusunya rumusan hasil pengumpulan data potensi wilayah dan akroekosistem, membuat rumusan hasil kebutuhan teknologi spesifik lokasi yang sesuai dangan kebutuhan petani, membuat program perbaikan yang mengakomodir kevutuhan petani, menyusun rencana kerja yang jelas, terukur dan trealisasi,dan menyusun metode perbaikan yang sesuai dengan materi perbaikan dan karakteristik petani.

Pelaksanaan modal, luas lahan, teknologi dan pupuk meliputi pelaksanaan pembelajaran usaha tani kakao, memperbaiki materi model yang sesuai dengan kebutuhan yang bervariasi dan sesuai dengan kebutuhan dan karakteristik petani, menerapkan metode perbaikan yang berpariasi dan sesuai dengan materi perbaikan dan karakteristik petani dan mengembangkan kelompok tani manjadi kelompok yang lebih besar terkait dengan pengembangan usaha taninya.
Evaluasi dan pelaporan modal, luas lahan, teknologi dan pupuk meliputi melakukan evaluasi efektivitas program, mengumpulkan data tentang input, aktivitas, kehadiran peserta dan reaksi terhadap program membuat laporan dan rencana tindak lanjut, mengevaluasi dampak perbaikan dan komunikasikan hasil evaluasi kepada pihak-pihak terkait.

Pengembangan modal, luas lahan, teknologi dan pupuk meliputi menyusun pedoman teknis dan pelaksanaan perbaikan untuk acuan perbaikan dalam melaksanakan tugasnya, merumuskan hasil kajian arah kebijakan perbaikan, dan merumuskan hasil konsep baru metode perbaikan.

Pengembangan profesi modal, luas lahan, teknologi dan pupuk meliputi ikut serta atau aktif dalam perkumpulan profesi tingkat kabupaten, provinsi dan nasional, mengakses informasi menggunakan internet, mengikuti kegiatan magang atau studi banding, dan membuat tulisan ilmiah atau populer dan diterbitkan dalam majalah atau surat kabar.

Kemampuan modal, luas lahan, teknologi dan pupuk meliputi menerapkan gaya kepemimpinan, menerapkan keterampilan memipin, menumbuh kembangkan kelompok tani, dan mengembangkan kepemimpinan kelompok tani.

Diseminasi teknologi meliputi penggunaan media cetak atau audio visual, melakukan pameran teknologi pertanian, tingkat penggunaan komunikasi tatap muka, melakukan studi banding, dan tingkat penggunaan cetak percontohan.

Komunikasi modal, luas lahan, teknologi dan pupuk meliputi membuat media perbaikan, memahami dan mendengarkan petani, 
menjelaskan, memberi inspirasi, berterimaksih dan toleran terhadap petani, mendorong dan membantu petani untuk maju dan mencapai tujuan dan mendisiplinkan diri dan memotivasi petani.

Kemitraan usaha meliputi mencari mitra usaha, mengidentifikasi sumber-sumber permodalan lokal, membimbing pemupukan modal usaha, dan membimbing penyediaan agro input, penyimpanan dan pemasaran hasil.

Melakukan teknis budidaya kakao meliputi mempersiapkan lahan, membibitkan kakao, melakukan penanaman, melakukan konservasi dan persiapan lahan melakukan pemangkasan dan pemupukan, melakukan pengendalian hama, penyakit dan gulma, melakukan panen dan pasca panen buah kakao.

Perubahan kinerja penyuluhyang berpengaruh nyata pada kinerja mereka, memperkuat teori Robbins (Veitzal, 2004), sebagian (2002), Gibson (2001) dan Atmosoeprapto (2004). Keempat teori tersebut pada umumnya menyatakan bahwa kinerja adalah fungsi interaksi antara kemampuan atau ability, motivasi atau motivation dan kesempatan opprtunity, tugas yang tepat dan lingkungan kerja. Kemampuan yang tinggi dan didukung oleh motivasi yang tinggi pula akan memberikan sesuatu yang baik berupa produktivitas yang lebih baik (produktif).

Menurut hasil penelitian pengaruh kompetensi menyumbangkan pengaruh yang paling besar pada kinerja yang dilakukan dengan perbaikan. Hal ini ditunjukan oleh koefisien berpengaruh sebesar $-0,131,0,88,0,029,0,096$ satuan. Karena itu, pengubah kompetensi harus dijadikan fokus dalam peningkatan perbaikan kinerja. Dalam hubungan ini kemampuan perbaikan untuk merencanakan program mengevaluasi dan membuat laporan perlu dikembangkan.

\section{SIMPULAN}

Berdasrkan pembahasan hasil penelitian, menunjukkan bahwa pengubah kinerja modal, luas lahan, teknologi dan pupuk pertanian berpengaruh nyata dan siknifikan terhadap kompetensi petani kakao dikecamatan bua kabupaten luwu.

\section{DAFTAR PUSTAKA}

Aspari, Ni Wayan Ayu Yuni. 2011. Analisis Skala Ekonomis dan Efisiensi Penggunaan Faktor-Faktor Produksi Pada Usaha Perkebunan Kopi di Desa Plaga Kecamatan Petang Kabupaten Bandung. Skripsi. Denpasar: Program S1 Reguler Jurusan Ekonomi Pembangunan Universitas Udayana.

BPS.Jawa barat Dalam Angka. (Online). (http://jbptunikompp-gdl-enengnunur15377-3-babii). Diakses tanggal 27 Desember 2014.

Hardiana. 2013. Faktor-Faktor yang Berpengaruh terhadap Peningkatan Pendapatan Petani Rumput Laut Eucheuma cattoni di Desa Barua Kecamatan Bua Kabupaten Luwu. Skripsi. Palopo: Program Studi Ekonomi Pembangunan.

\section{http://id.wikipedia.org/wiki/Teknologi}

http://datakata.wordpress.com/2014/11/28/definisimodal-kerja

Kasmil. 2010. Peranan Pola Intensifikasi Tanaman Kakao dalam Meningkatkan Pendapatan Petani di Kecamatan Bua Kabupaten Luwu. Skripsi. Palopo: Program Studi Ekonomi Pembangunan. 
Miller and Roger Meiners. 2000. Teori Mikroekonomi Intermediate, PT. Raja Grafindo Persada. Jakarta.

Mubyarto. 2002. Ekonomi Pertanian, Edisi Kedua, PT. Raja Grafindo Persada, Jakarta.

Nasution Rusdiah. 2008. Pengaruh Modal Kerja, Luas Lahan, dan Tenaga Kerja terhadap Nenas, Universitas Sumatera Utara, Medan.

Nurianti. 2013. Pengertian Teknologi Menurut Umum. (Online). Diakses tanggal 27 Desember 2014.

Nuraini Ida. 2001. Pengantar Ekonomi Makro. Universitas Muhammadiyah. Malang.

Sadono Sukirno, 2002. Pengantar Teori Mikroekonomi, edisi ketiga, PT. Raja Grafindo Persada, Jakarta.

Soekartawi. 1993. Prinsip Dasar Ekonomi Pertanian-Teori dan Aplikasi. PT. Raja Grafindo Persada, Jakarta. . 1995. Agribisnis: Teori dan Aplikasi, Cet 3, PT. Raja Grafindo Persada, Jakarta.

Sugiono. 2007. Statistika Untuk Penelitian, Alfabeta, Bandung.

Tiro, Arif. 2000. Dasar-Dasar Statistika, UNM Makassar, Makassar.

Tohir. 1991. Seuntai Pengetahuan Usahatani Indonesia. Rineka Cipta. Jakarta.

Wasis. Pengantar Ekonomi Perusahaan, Alumni 1992, B 